\title{
Neoplatonic Symbolism by Michelangelo in Sistine Chapel's Separation of Light from Darkness
}

\author{
Ian Suk and Rafael J. Tamargo
}

\begin{abstract}
Upon discovery of Michelangelo's concealed neuroanatomical images in "Separation of Light from Darkness," by Suk and Tamargo in 2010, there remained a compelling need to investigate in greater detail the reasoning behind Michelangelo's depiction of imagery of the brain, brainstem, spinal cord, eyeballs and optic nerves in the Sistine Chapel. At cursory glance, "Separation of Light from Darkness" depicts God's first act of Genesis 1:3-5 (King James Bible), in which he creates light and separates it from the darkness, enveloping the world he has just created. It is a seemingly simple, conspicuous act, but careful analysis reveals that Michelangelo used his artistic, academic, and poetic genius to embed layers of symbolic meanings. The authors believe that the great artist infused a visual metaphor of a scene from Plato's "Allegory of the Cave" in Book VII of The Republik $(\sim 380 B C)$ to represent his key ideologies in Neoplatonism and pious convictions.
\end{abstract}

Michelangelo painted the Sistine Chapel during the flourishing period of High Renaissance ( 1475-1527). High Renaissance art followed and reflected the period of 'rebirth' in which philosophy, literature, art, and sciences drew on ancient knowledge from Classical Antiquity, principally the ancient Greeks. The Renaissance was a period of rapid growth where people applied new found knowledge to the Classical Greek studies of Socrates, Plato, and Aristotle (from about the 4th to $3 \mathrm{rd}$ century $\mathrm{BC}$ ). One of the most influential ancient philosophers was Plato ( 428-348 BC) whose teachings propagated throughout Athens for about two centuries around his lifetime, through his established school, the Academy. His philosophy of Neoplatonism was resurrected by an Italian baron, Cosimo I de Medici who employed Marsilio Ficino (1433-99) to lead the Florentine Platonic Academy (of which Michelangelo was a student) and translate all of Plato's writings into Latin.

Through analysis of Michelangelo's paintings, his preliminary sketches, poems, written letters, and the political and religious context of his time, the authors attempt to provide key evidence to reveal the meaning and symbolism behind Michelangelo's concealed anatomic representations.

\section{OPEN ACCESS}

\section{Keywords}

Michelangelo, anatomy, neuroanatomy, Sistine Chapel, neoplatonism, symbolism

\section{Introduction}

Neoplatonism, a metaphysical philosophy that has analogous doctrines to early Christianity, flourished during the Renaissance. It is suffused with symbolic references to astronomy, mathematics, and naturalism in order to explain the origin of the human soul. The ultimate Source of Being or 'The One' is analogous to the religious counterpart of God. Three realms of Neoplatonism include: The One, the Soul, and the Material (or Phenomenal) World. The Soul, which is an immaterial state of being, is the intermediary between The One and the lower realm of the Material, or bodily, world.

In 2009, Suk and Tamargo identified key neuroanatomical images, cleverly hidden within the image of "God Separating Light from Darkness." (Figures 1 \& 2) Unlike other master painters, Michelangelo was also an accomplished poet and scribe. Although he wrote the strongest of his Neoplatonic inspired texts during middle age, careful review of some of his poems and dialogues reveals deep insights into his introspective character, religious beliefs, and motivations that pervaded his entire life.
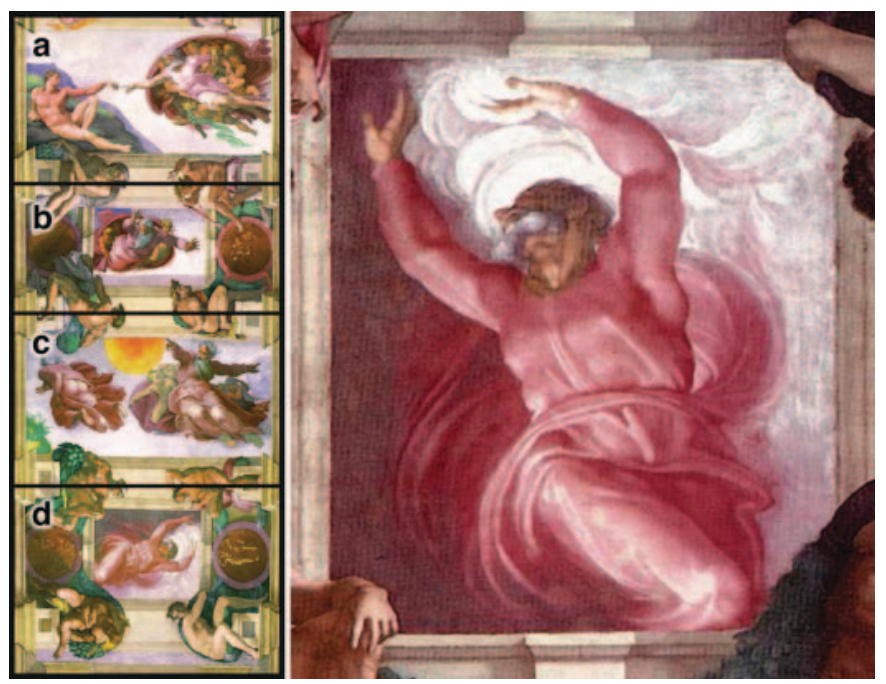

Figure 1. The last four panels painted by Michelangelo along the longitudinal axis of the Sistine vault are the Creation of Adam (Genesis 1:2627), Separation of Land and Waters (Genesis 1:9-10), Creation of the Sun and Moon (Genesis 1: 14-19), and Separation of Light from Darkness (Genesis 1: 3-5). These panels are stylistically different from the first five and were painted as a separate series over a period of about a year, starting in the winter of 1511 after a hiatus of at least six months.

The Separation of Light from Darkness was one of the last Sistine frescoes painted by Michelangelo. It depicts the first act performed by God in the creation of the universe (Genesis 1: 3-5). This final panel has a special location in the Sistine chapel, as it is situated directly above the altar. (Suk 2010) [Originally published as Figure 1 in Neurosurgery, Volume 66, Issue 5, 1 May 2010, Pages 851-86] 


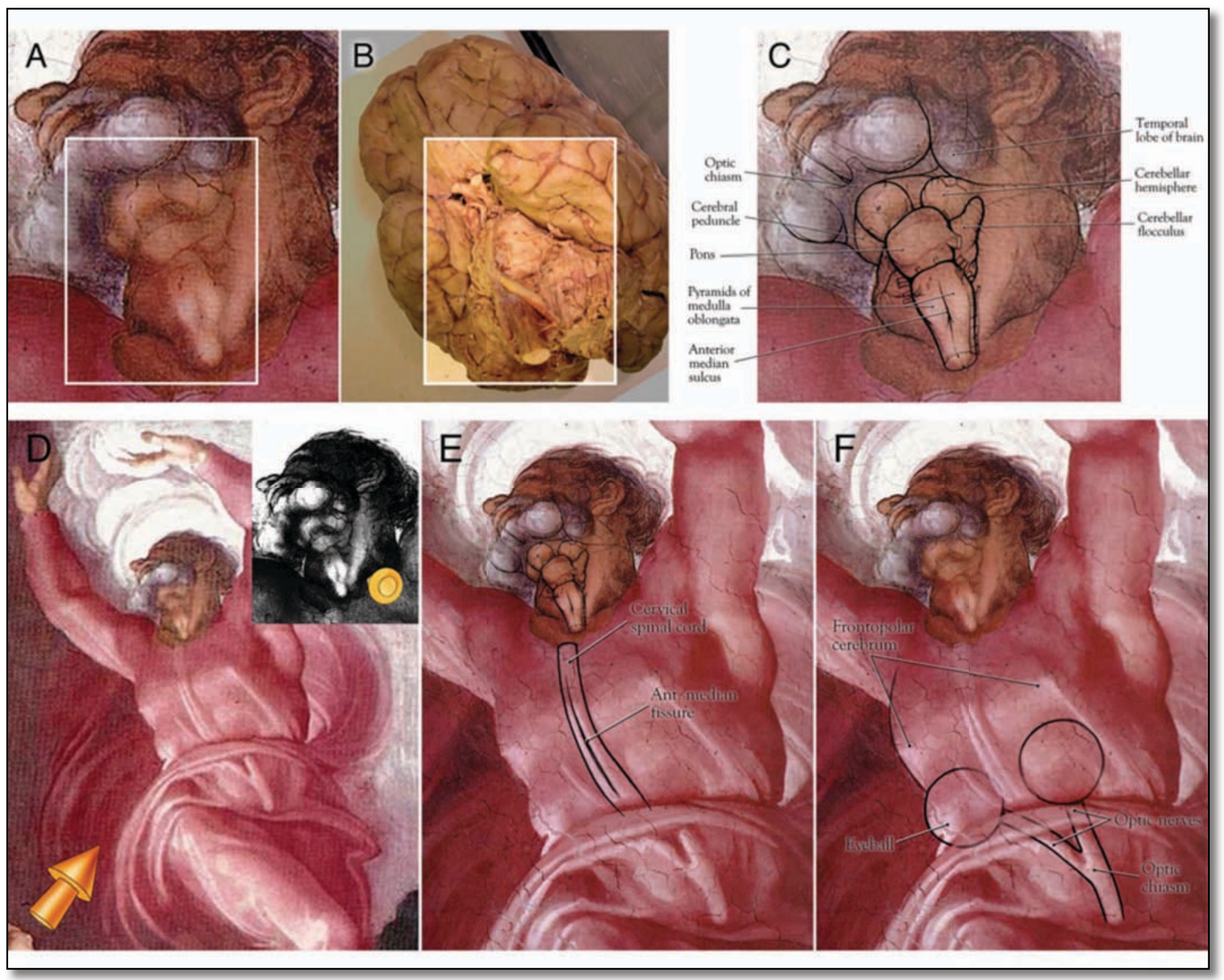

Figure 2. Comparative view of brainstem landmarks in the Separation of Light from Darkness. Brainstem anatomy in highlighted box by Michelangelo (A) is compared with a similar area outlined in a cadaver dissection (B). In (C), the overlay shows the specific midbrain structures that correspond to the unusual features in God's neck depicted by Michelangelo. In (D), there are two different light sources. One from bottom right and another originating from the viewer towards the neck (inset). Concealed images depicting the upper cervical spinal cord (E) and eyeballs and optic nerves and chiasm (F). (Suk 2010) [Originally published as Figure 4 in Neurosurgery, Volume 66, Issue 5, 1 May 2010, Pages 851-86]

The brainstem, spinal cord, eyeballs, optic nerves and chiasm are symbolic elements that have meaningful representations in the Neoplatonic world. (Clements 1954, Clements 1961, Clements 1965, Clements 1968, Saslow 1991, Vess 1998, Yhap 2003) The study of philosophy in Platonism and Neoplatonism is indeed vast and even a modest analysis is well beyond the scope of this manuscript. The authors therefore, attempt to simplify and graphically outline key general principles, and submit the best literary and graphic examples to explain Michelangelo's neuroanatomic images. (Figure 6) The abundance of existing literature both from Michelangelo himself, his biographers, and the documented political climate of his time, all help elucidate the anatomical metaphors in his paintings.
Many elite thinkers of his period subscribed to Neoplatonic views to understand the world around them. (Blunt 1940, Burckhardt 1954, Robb 1935) Based on classical Greek philosophers, Plato (ca 428-328 B.C.) and Plotinus (ca AD 204-270) understanding of the metaphysical and religious worlds lies at the heart of Neoplatonism. Michelangelo composed several hundred sonnets, madrigals (musical lyrics), and other poems throughout his productive life (1475 -1564). (Taylor 1960, Miles 1999, Yhap 2003) He is the first artist to produce such a large body of work in both visual and verbal media. (Saslow 1991) Only Leonardo da Vinci left a greater body of written data but his volumes of manuscripts were mostly scientific and did not clearly reveal the introspective thoughts or symbolic beliefs of the artist that characterized the personal revelations of Michelangelo. (Casson 1977, Clayton 1992, Clements 1968) 


\section{Neoplatonic Symbolism of Plato's “Allegory of the Cave"}

The authors believe that Michelangelo symbolically depicted the archetypal Neoplatonic elements from Plato's “Allegory of the Cave" (from Republik-Book VII) ( 380BC) within his Separation of Light from Darkness panel. In this famous dialogue, Socrates (470BC-399BC), the great Greek philosopher explains to Glaucon (Plato's brother) the analogy of prisoners chained to a cave their entire lives, who eventually escape the darkness and shadows. He compares this with man's ascension from ignorance to receiving enlightenment and seeing the truth. (Figure 3)

Socrates explains that this group of prisoners, who were chained by their legs and necks on the floor of the cave, so that they could not get up or turn their necks, can only see one wall in front of them. Behind them is a fire that they cannot turn to see directly. Between them and the fire is a path for other people and things to parade through, and the moving objects cast shadows on the one wall that the prisoners can see.
The prisoners give names to these shadows and they exist as the only reality that they know and understand. When they are freed, they can turn and see the fire directly, which causes their eyes pain, and finally they see the real objects. It takes a lot of time to leave the cave and adjust to the even brighter sunlight that is emanating from the cave entrance behind them. Once enlightened, it is difficult to return to the cave. This allegory is one of Plato's greatest archetypal symbolisms representing man's ascension to the Truth in 'Ideas and Forms' from the imprisonment of representative 'Reflections of Material Forms'. Shadows and reflections are mere false representations of the 'Idea' of the true object.

This is a tour de force of symbolism in which Michelangelo fuses in a singular painting, obligations to Pope Julius II (who commissioned the Sistine Chapel project), archetypes of Christianity, political and religious reformation, and the highest reverence for Neoplatonism. His religious devotion to the Church, understanding of Neoplatonism, and lifetime struggle to seek truth and divinity, all culminate in the symbolic depiction of the image that sits above the altar.

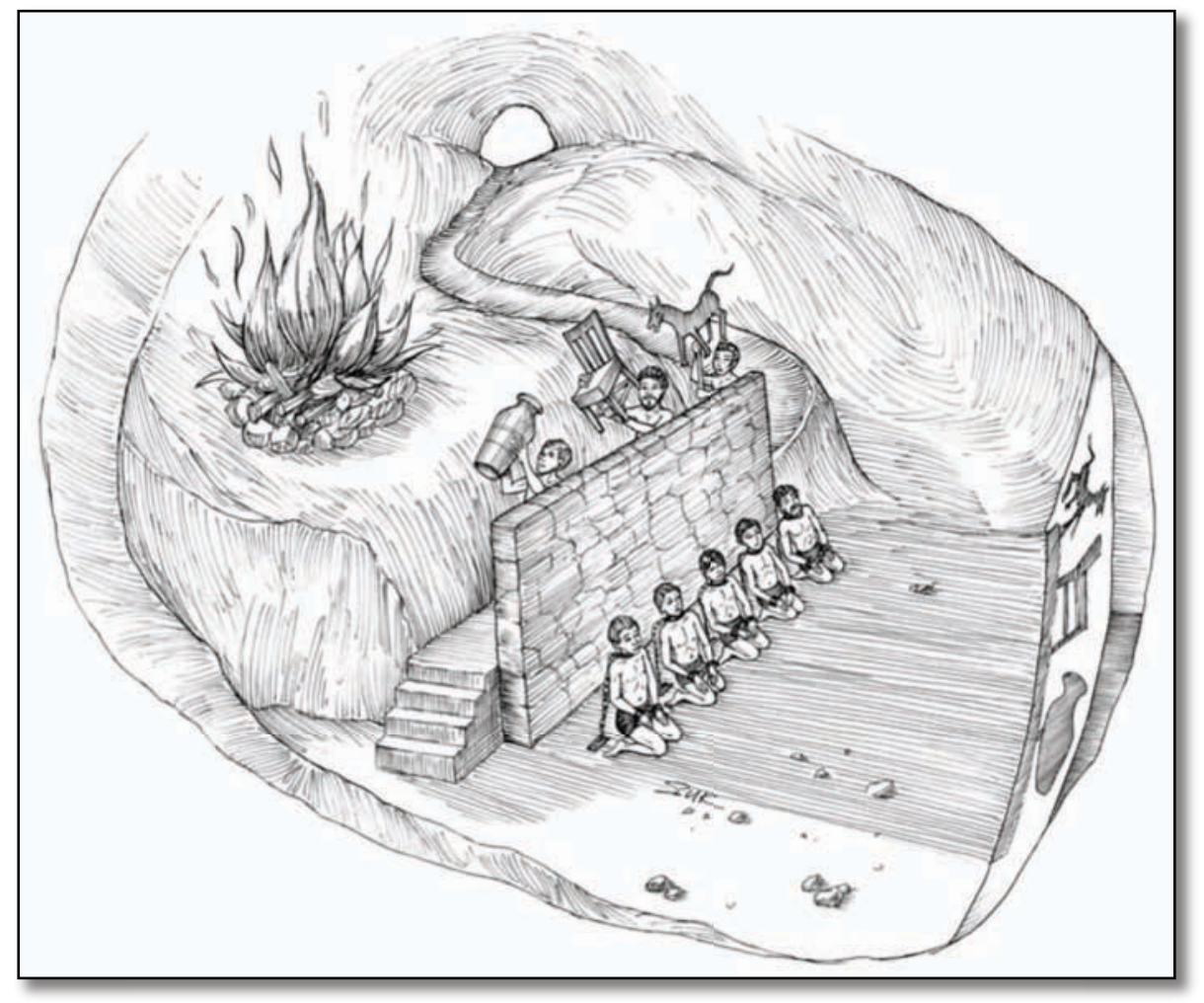

Figure 3. Allegory of the Cave.

Artistic depiction of the main scene from Plato's Republik-Book VII Allegory of the Cave.( 380BC). In this famous dialogue, Socrates (470BC-399BC), the great Greek philosopher explains to Glaucon (Plato's brother) the analogy of prisoners, chained to a cave their entire lives, who eventually escape the darkness and shadows, and he compares this with man's ascension from ignorance to receiving enlightenment and seeing the truth. The prisoners are chained by their legs and necks on the floor of the cave, so that they cannot get up or turn their heads and can only see one wall in front of them. Behind them is a fire that they cannot turn to see directly. Between them and the fire is a path for other people and things to parade through, and the moving objects cast shadows on the one wall that the prisoners can see. The prisoners give names to these shadows and they exist as the only reality that they know and understand.

When they are freed, they can turn and see the fire directly, which causes their eyes pain, and finally see the real objects. It takes a lot of time to leave the cave and adjust to the even brighter sunlight that is emanating from the cave entrance behind them. Once enlightened, it is difficult to return to the cave. CIan Suk. All rights reserved 


\section{Analysis of Sketches}

In Figure 4, Michelangelo explores different ways of sketching the grand gesture of God, seemingly creating light within the universe. The Separation of Light from Darkness panel has some unique properties that are very different than all other panels in the Chapel. (Figure 1) Despite the fact that it is one of the final panels painted at the completion of the four-year endeavor, it appears very crude, gestural, and monochromatic by comparison. Moreover, the face of God is barely visible from its awkward hyper-extension of the neck and turned head. The other panels depict God in a much more prominent frontal or lateral view. (Figures 1A-C, 5A-C) They are more colorful and are dramatically depicted with austere characterizations.

The arms of God have grand poses with hands in grasping or pointing gestures. The varying expressions of God are severe. The flowing white hair and beard also help to reinforce the powerful and monolithic acts in each scene. In the Separation panel however, all these cues are absent. Instead, the head is bent backwards and turned to the right - almost as if the figure is trying to look backwards. The expression can be interpreted as one reaching out for something at the same time or trying to avert one's eyes from a bright light, blocking out the rays with the hands.

Figure 4 shows Michelangelo's initial sketches for the Separation panel. Three separate gesture line drawings show the figure with outstretched arms in various states of a 'reaching motion'. From an outstretched Y-shaped position (4B) to a moderate position (4C) and to a closelyapproximated gesture (4D), they all show effectively the active tension created as God creates this light for mankind. One can discern Michelangelo's struggle to figure out the orientation of the arms and hands. The final painting in the Chapel (Figure 5D) interestingly, seems to be the most awkward and physically contorted one, especially for someone who is in the monumental act of creating light within the universe. The brightest light emanates from around the head, seemingly behind God.

Would God in his infinite power in illuminating the universe, avert his eyes and grimace at the sudden brightness that he himself created? The final painted figure depicts the most uncomfortable position of the upper limbs and shows the hands in extreme pronation and extension (wrists extremely inverted and extended). Close scrutiny of the position of the thumbs clearly reveals this extreme pronation and extension. This highly non-dexterous pose is incongruous with the commanding and deliberate nature of this monumental act of creation. The authors contend that this depiction of God also represents the freed prisoner in Plato's allegorical Cave reaching towards the entrance that is situated above and behind him, while at the same time shielding himself from the sudden bright light with his hands.

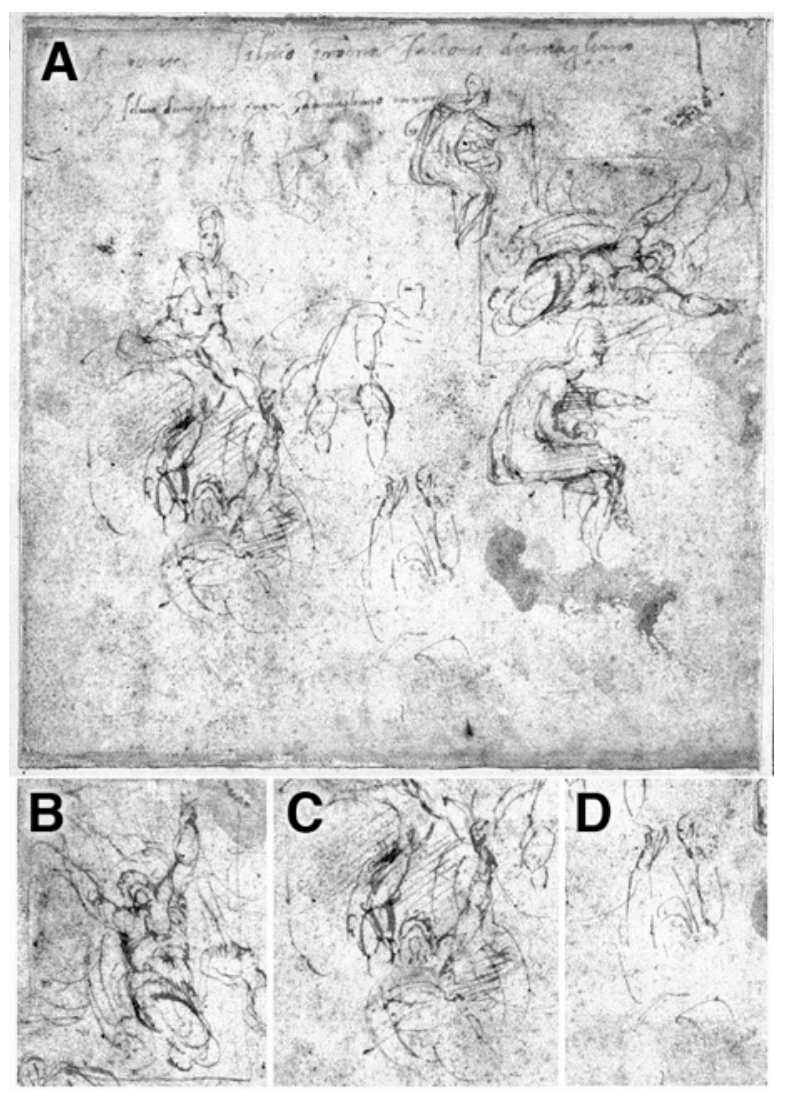

Figure 4. Michelangelo's sketches showing preliminary drawings for the Separation of Light from Darkness panel in the Sistine Chapel. (ca 1512) WA1846.47 Michelangelo 'Eight Figure Studies' (PII 301) (CAshmolean Museum, University of Oxford. [Ashmolean Museum of Art and Archeology Oxford University]

Three separate gesture line drawings show the main figure with outstretched arms in various states of a 'reaching motion'. (B-D) From an outstretched Yshaped position (4B) to a moderate position (4C) and to a closelyapproximated gesture (4D), they all show effectively the active tension created as the God figure creates this light for mankind. One can discern Michelangelo's struggle to figure out the orientation of the arms and hands. It is interesting that the final rendered panel shows the hands and arms in the most contorted posture with the arms closely approximated and the wrists in extreme pronation and extension.

\section{Logos Symbolism}

This figure of God symbolizes 'Logos' which in Neoplatonic philosophy represents the intermediary being between the divine 'One' and the material world. (Boortin 1993) Traditional Christianity translates 'Logos' as 'The Word' and would personify 'Logos' as Jesus who is a material manifestation of God, who also acts as the bridge between God and secular man. Similarly, the Hebrew Bible mentions Logos as 'Angel of the Lord' who is God's instrument in the creation of the universe. This deeply symbolic concept of an intermediary body ascending upwards towards the heavens corresponds with the painting's sacred position above the altar. 
After four years of painting arduous masterpieces in the Sistine Chapel, it stands to reason that Michelangelo would approach this panel with the highest order of intelligence, religious conviction, symbolism, and divine talent. He wasn't merely representing a prosaic scene from the Bible, but as his magnum opus, exploring the deepest philosophical origins of the human soul, God, and the universe.

\section{Light Source \& Ideal Compositional Movement}

In the Separation panel, if this were solely God creating light from a world of darkness, there would only be a singular light source emanating from a point of origin around his hands and head. Instead, there is a disparate secondary light source coming from the bottom left corner of the picture [Suk and Tamargo 2010, Figure 5A]. This would directly correspond with the light from the fire in the "Allegory of the Cave". This is the fire that cast shadows of the objects that were paraded behind the prisoners. The brightest light around the head represents the entrance of the Cave, towards which the head and twisting body is reaching.

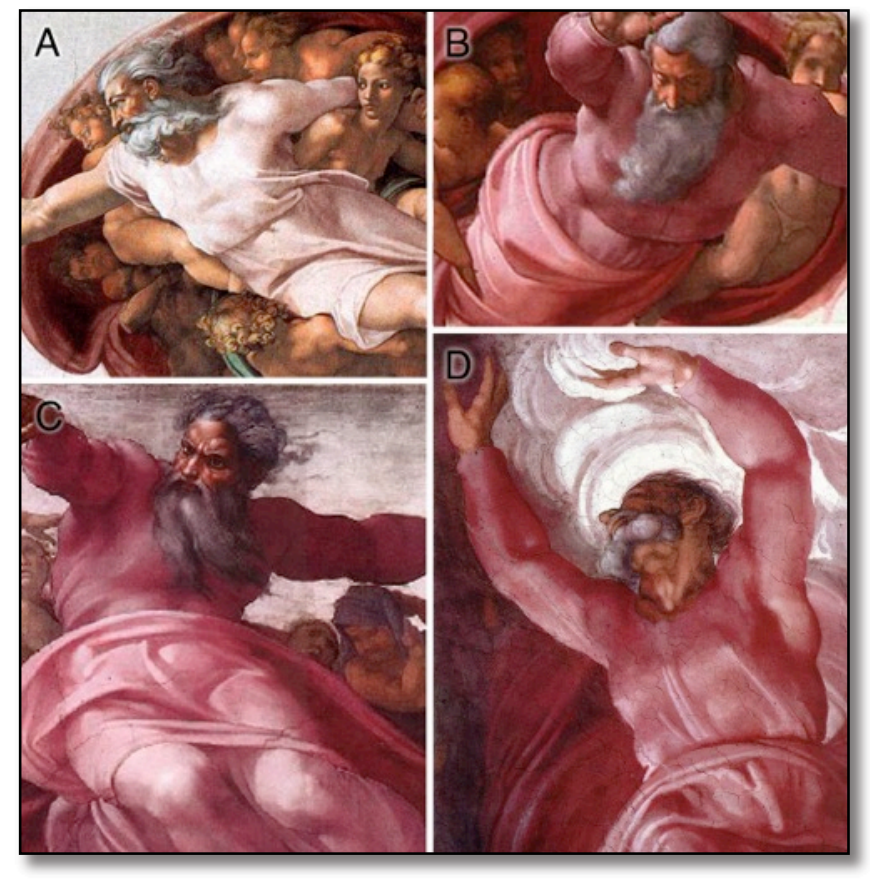

Figure 5. The last four panels painted by Michelangelo along the longitudinal axis of the Sistine ceiling are the Creation of Adam (Genesis1: 26-27), Separation of Land and Waters (Genesis 1: 9-10), Creation of the Sun and Moon (Genesis 1: 14-19), and Separation of Light from Darkness (Genesis 1: 3-5). (Suk 2010) [Originally published as Figure 1 in Neurosurgery, Volume 66, Issue 5, 1 May 2010, Pages 851-86]

From $\mathrm{A}-\mathrm{D}$, one can sense the progressive speed of artistic rendering by the gestural "sketchiness" of the panels, as well as simplification of forms. In Separation of Light from Darkness panel, which was painted in one day, the brushstrokes are rougher and more crudely done than all the rest (Casson 1977, Vasari 1998). Also notable is the face of God being mostly hidden and less "finished" compared to other panels and reveals the least facial character and color compared to the other depictions of God.
The stark contrast between darkness and light is reinforced in the image in two diagonal halves of the painting. The lower left half of the panel is mostly in darkness and the upper right half is bathed in light, symbolizing the disparate material and divine worlds. The dynamic figure shows a dramatic twisting movement bridging the dark and light worlds from the bottom right corner to upper left. This serpentine motion, combined with a 'contrapposto' stance, are key examples of classical forms and divine compositions that marked Neoplatonic ideology. (Suk 2010) ....The upwardly twisting motion of the body and counterbalance of opposing physical stances were considered by Michelangelo to be of the highest idealized movement and composition. The 'figura serpentinata' was a canon of aesthetically ideal form in the High Renaissance. (Summers 1972)

\section{Michelangelo's Spiritual Ascension through High Art Symbolism}

When Michelangelo was 15, he was taken into the household of Lorenzo de'Medici, the most powerful leader of Florence. Here, Michelangelo flourished from his exposure to the best Neoplatonic philosopher Marsilio Ficino (1433-1499), poet Angelo Signorelli, architect Giuliano da Sangallo, and painters, Sandro Botticelli, and Luca Signorelli. (Burckhardt 1954, Condivi 1903, Kristeller 1943, Robb 1935, Vasari 1998) It is believed that Michelangelo attended and absorbed Neoplatonic doctrines from the Platonic Academy (Florentine Academy), which was a 'study group' of elite thinkers led by Marsilio Ficino. The group was modeled after the ancient Plato's Academy and supported by Cosimo de Medici and dissolved soon after the death of his successor, Lorenzo de Medici in 1492.

The poetry throughout his lifetime reflected a symbolic struggle between the religious puritanical Christian influence and the more pagan and mythical beliefs of neoclassicism. (Clements 1961) The two prevalent worlds of his period were not mutually exclusive (Blunt 1940, Burckhardt 1954, Miles 1999, Saslow 1991) and Figure 6 illustrates the combined analogous parity between the two Florentine worlds.

\section{Dual Religious/Philosophical Analogy}

Neoplatonic ideas were not only popular amongst the educated elite, artists, and aristocracy, but they reflected in many ways, the desire for the common individual to independently "ascend" the strata himself, to be in the sphere of pure idea, form, and intellect. (Robb 1935, Stephens 1990) The latter are intangible, unchanging forms that are spiritually analogous to the 'Divine' or God in Puritanical Christianity. (The upper ovals outline these highest levels in Figure 6 A and B). Figure 6 provides a graphic synopsis of the two prevalent belief systems during Michelangelo's life in Florence and puts into context the individual symbolic neuroanatomic images. 


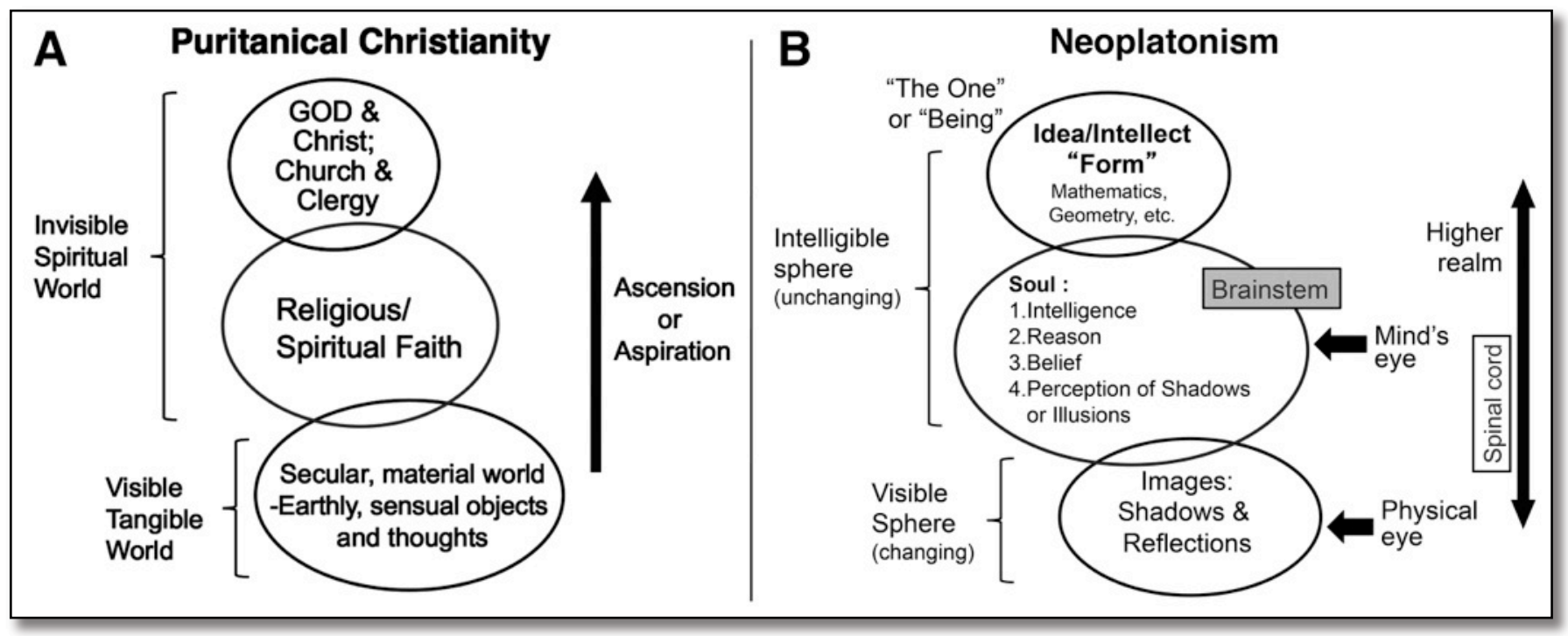

Figure 6. Graphic outline of the two prevalent religious orders in Florence during High Renaissance. Comparative beliefs in Puritanical Christianity (A) shared structural parallels with Neoplatonism (B). God and the clergy and Religious faith comprise the Invisible World and the Secular world of materialism and earthly sensual objects comprise the Visible, Tangible World. In the Neoplatonic realm, the Intelligible sphere includes the Idea/Intellect or pure Form and the Soul (which encompasses intelligence, reason, beliefs, and Perception of Shadows or Illusions). The Visible Sphere which comprises of physical Images-both shadows and reflections, has parity with the realm of the Visible, Tangible World in Christianity.

The concealed Brainstem is the physical locale of the "senso commune" or the Soul and would be located within the central oval in B. The eyeballs and optic nerves have representations in the Soul of the Intelligible Sphere and as the physical conduit for Shadows and reflections, of the lower Visible Sphere. The upper spinal cord, which physically connects the brainstem with the rest of the body symbolizes man's individual ascension to the higher spiritual realms, as represented by the solid arrows (A and B). In Neoplatonism, the arrow is bi-directional, which signifies the upper realms having influence and being able to control the lower realms.

Within Christianity, there were two worlds: 1 . 'Traditional doctrine' of the high order of the Catholic church ruled by the Pope acting as the intermediary between man and God and 2. secular mankind. They are largely organized into the Invisible Spiritual World and the Visible Tangible World. A parallel organization exists in Neoplatonism: 1. The Intelligible Sphere and 2. The Visible Sphere. Progressive thinkers however, believed that the common man could ascend the strata directly and approach divinity without the intermediary of the Pope and cardinals or other political groups. This kind of liberal thinking surged during the late renaissance in western Europe, and Michelangelo's literary expression shows a deep affinity and understanding of Neoplatonism during a period marked by strong influence from Catholic orthodoxy in Florence. (Burckhardt 1977, Robb 1935)

What is important is not so much the differences of the dual religious worlds, but rather to understand Michelangelo's passionate religious devotion by the use of artistic symbolism to ascend to a higher spiritual plane. In this way, the realms of Puritanical Christianity and Neoplatonism share more structural parallels than differences. It is this profound and deliberate introspective use of artistic symbolism to elevate himself to higher spiritual levels that sets him apart from other elite painters. (Boorstin 1993) The brainstem in Figure 2E symbolically represents a component of the Soul (Figure 6B), where resides the four basic precepts: intelligence, reason, belief, and perception of shadows. (Burckhardt 1977, Robb 1935)

\section{Anatomic Location of the Soul}

Science and experimental reasoning flourished during the High Renaissance period ( 1475-1527). (Burckhardt 1954) The quest for understanding the human mind and search for the human soul blossomed from precedent Neoplatonism, Galenic principles, and Christian backgrounds. (Vasari 1998) Galen (A.D. 129-201, a Greek anatomist and physician) explained that the human mind functioned by using a flow of information between cells in the head - and this gave rise to the popular "cell doctrine" of human understanding which postulated that humors flowed through several specialized compartments in the brain. (Clarke 1996) (Figure 7) This theory was popular from the middle ages to Late Renaissance period. The theory comprised of three cells through which flowed information and was responsible for all brain functions. Anatomically, they roughly correspond to today's ventricular system of the brain. The first cell represents the initial repository for information gained through the eyes and is named cell of imagination and fantasy. The second cell is a place of processing the info and is responsible for judgment, thought, and reason. The third cell located toward the occiput (back of the head), was thought to be where memory was stored.

In 1998, Del Maestro presented Leonardo da Vinci's exhaustive anatomic search for the human soul. (DelMaestro 1998) Even Leonardo initially subscribed to the cell doctrine and appropriately called them imprensiva or intelleto for cell one, senso commune for cell two, and memoria for the backmost 
cell in 1487 (Figure 8). (Clarke 1996, Da Vinci 1977, Del Maestro 1998) The senso commune was a term that Leonardo used and exists today - also used in a similar context, "common sense". [The original roots are believed to be derived from Greek philosopher Aristotle's sensus communis (384 BC-322 BC)].

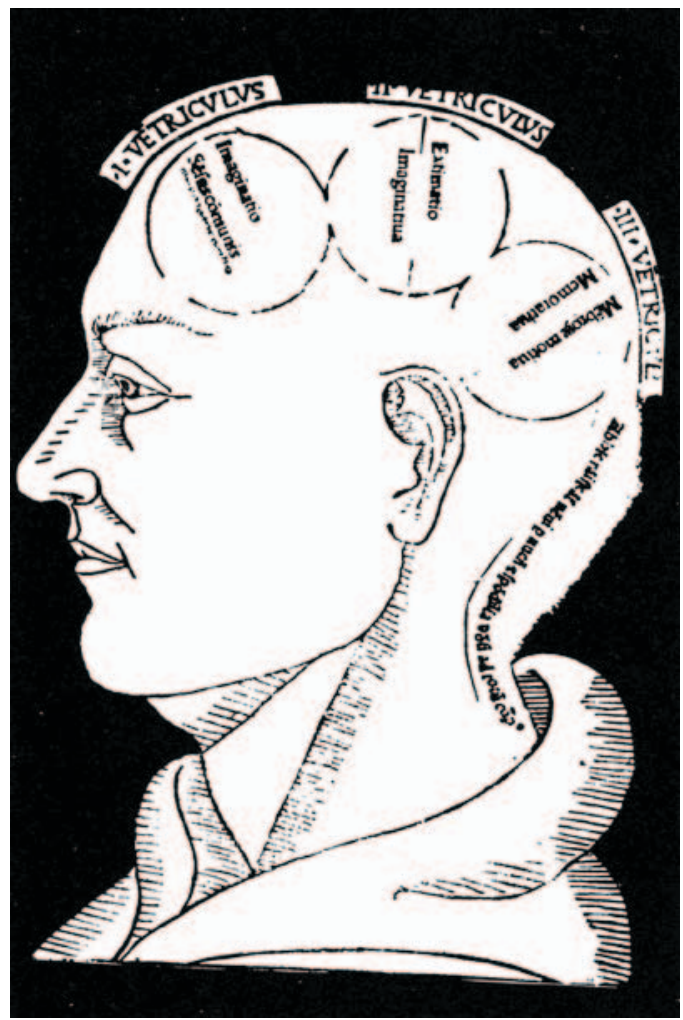

Figure 7. Illustration from a popular printed book by Albertus Magnus (1490). The "Cell doctrine", in which mental function was mediated by a flow of humor or gases through specific cells in the brain, remained dogma for over a millennium beginning with Galen (A.D. 129-201, a Greek anatomist and physician) and then popularized by early theologians of the 4th and 5th century. (Blunt 1940)

Several years later Leonardo injected hot wax into the ventricle cavities of the brain and upon dissection, the remaining wax left a clear impression of the ventricles and subsequently revised his understanding of the structure of the cells (Figure 9). (Da Vinci 1977, Del Maestro 1998) Today's lateral ventricles, he designated imprensivo, the third ventricle was senso commune, and the fourth ventricle became the place for memoria. Senso commune was believed to be the soul and "seat of judgment" where all the senses converged. He localized the soul to be precisely above the optic chiasm, in the anterior part of the third ventricle (Figure 10). (Clarke 1996, Da Vinci 1977, Del Maestro 1998) In Figure 2F, Michelangelo sharply highlights the optic chiasm, as a hidden fold in God's abdomen. (Stephens 1990)

Although it is unlikely that Michelangelo had academic knowledge of detailed brainstem function, anatomically it was the physical locale of the Senso commune/human soul and the area where the optic nerves and optic chiasm emanated. For a deep-thinking artist who had a lifetime obsession with anatomical dissection, depicting the brainstem would establish a very important symbolic representation of the soul and provide the gateway to a higher realm of the "Idea/Intellect and Form" (Figure 6B). (Condivi 1903, Vasari 1998) The brainstem in pictorial representation would therefore feed and exist as an integral part of the soul. The entire brain itself as discovered by Meshberger (1990), hidden in the "Creation of Adam" panel, would also exist in this upper spiritual realm. (Meshberger 1990, Suk 2010) In Figure 6, the solid arrows in neoplatonism as well as Puritanical Christianity, outline this upward movement, just as the upper spinal cord represents a gateway to the Divine. In 1954, Clements explained that the higher Ideal Form can also conversely affect and control the hand. (Clements 1954) The representation of the spinal cord, therefore would provide a symbolic connection also in the opposite direction, for the higher realm to influence manual artistic creations in the physical world.

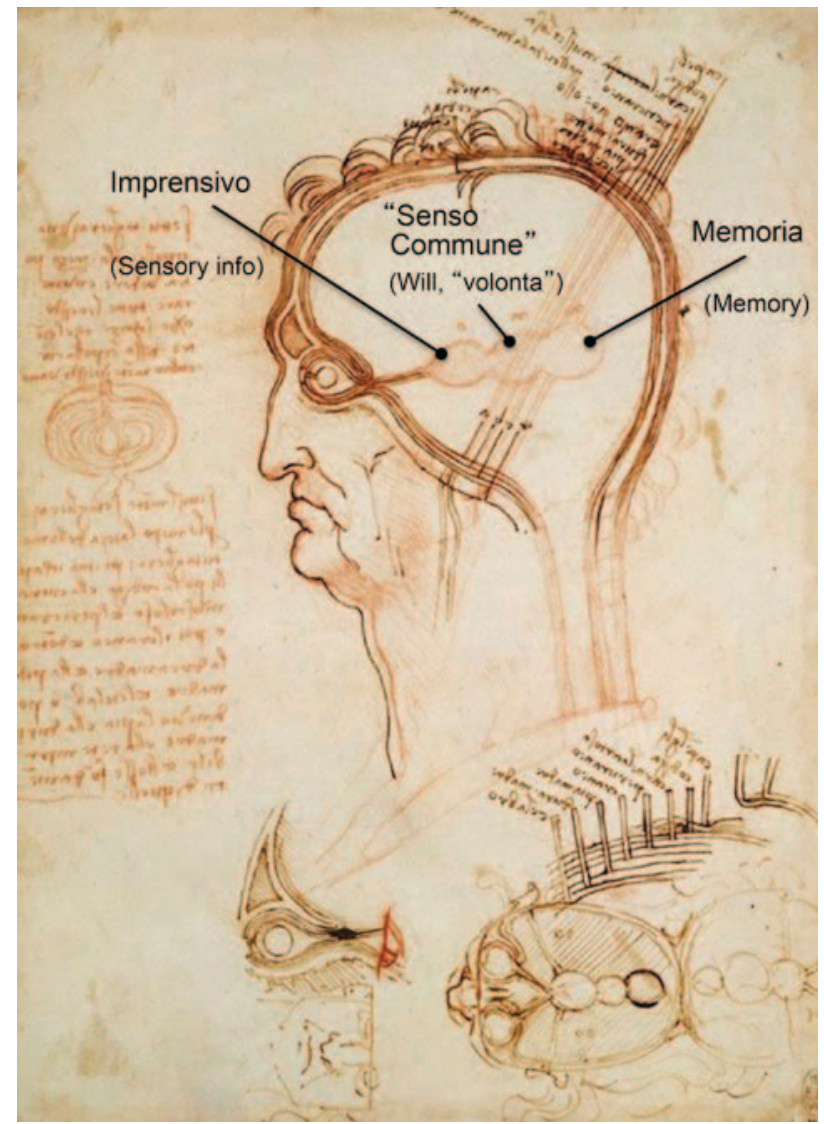

Figure 8. Leonardo da Vinci illustrates in sagittal and axial sections of the head the outlines of the "Cell doctrine" anatomy. It is apparent that despite Leonardo's rigorous science-through-experimentation practices, even he was misguided in his initial neuroanatomy concepts. He revises his understanding several years later by outlining the ventricles. (Figure 9) [Keele KD, Pedretti C: Leonardo da Vinci. Corpus of Anatomic Studies in the Collection of Her Majesty the Queen at Windsor Castle, 3 vols. New York: Johnson Reprint Company, 1979, 1980.] Recto: The layers of the scalp, and the cerebral ventricles. Verso: Studies of the head c. $1490-92$

Recto: Pen and ink, and red chalk. Verso: Pen and ink, discoloured white, and faded metalpoint $\mid 20.3 \times 15.3 \mathrm{~cm}$ (sheet of paper) $\mid$ RCIN 912603

www.jbiocmmunication.org 


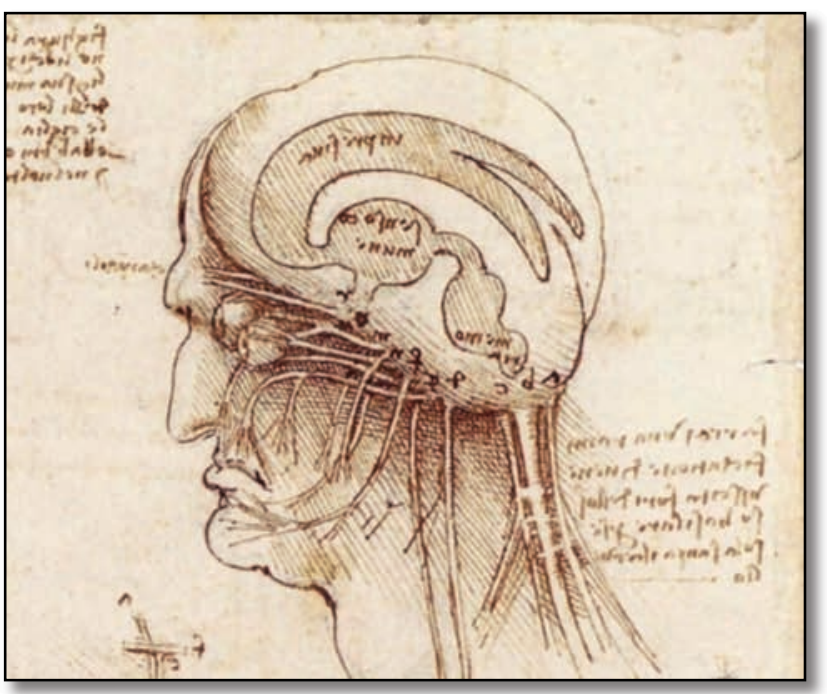

Figure 9. Landmark illustration by Leonardo da Vinci outlining the most accurate ventricles to date (ca. 1508-9) (despite his error in depicting bovine ventricles). After injecting melted wax into the ventricles, the soft tissues in the cranium was dissected away to reveal the organization of the lateral ventricles, third, and fourth ventricles.

[Keele KD, Pedretti C: Leonardo da Vinci. Corpus of Anatomic Studies in the Collection of Her Majesty the Queen at Windsor Castle, 3 vols. New York: Johnson Reprint Company, 1979, 1980.] The brain c.1508-9 Pen and ink over black chalk $\mid 20.0 \times 26.2 \mathrm{~cm}$ (sheet of paper) | RCIN 919127

Recto: Pen and ink, and red chalk. Verso: Pen and ink, discoloured white, and faded metalpoint | $20.3 \times 15.3 \mathrm{~cm}$ (sheet of paper) | RCIN 912603

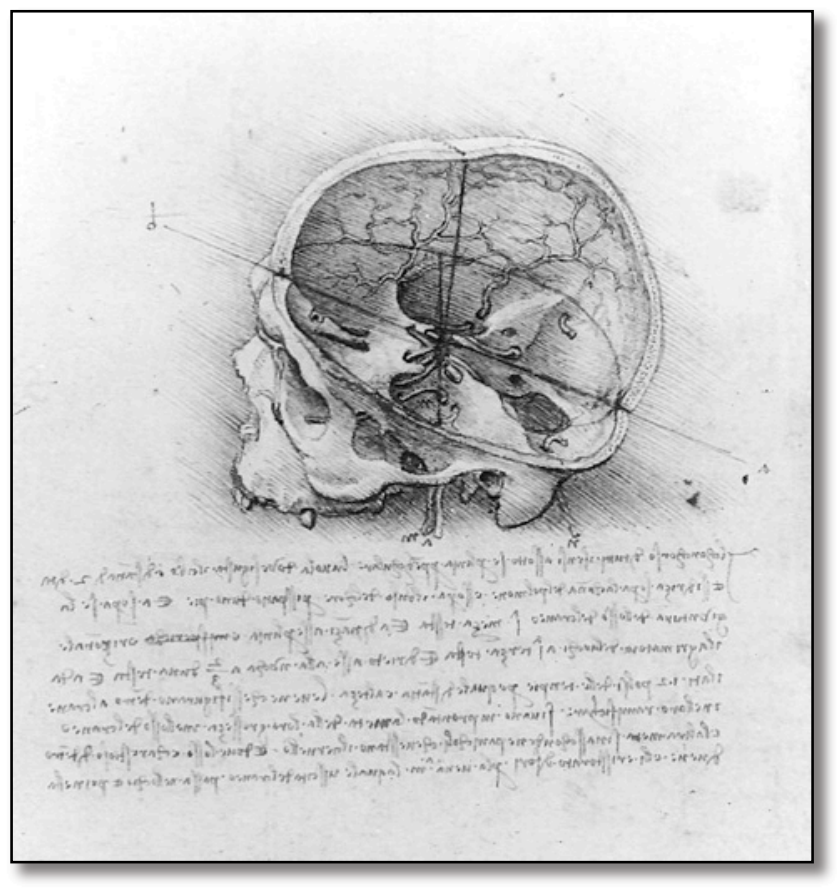

Figure 10. Location of the Soul in the senso commune and optic chiasm by Leonardo da Vinci (ca. 1489). After an exhaustive search, Leonardo pinpointed the location of the human soul to be just above the optic chiasm in the anterior portion of the third ventricle. (King 2003) [Keele KD, Pedretti C: Leonardo da Vinci. Corpus of Anatomic Studies in the Collection of Her Majesty the Queen at Windsor Castle, 3 vols. New York: Johnson Reprint Company, 1979, 1980.] Recto: The cranium sectioned. Verso: The skull sectioned 1489. Recto: Pen and ink. Verso: Pen and ink over traces of black chalk $19.0 \times 13.7 \mathrm{~cm}$ (sheet of paper) | RCIN 919058

\section{Human Eye Symbolism}

In Neoplatonism, the human eye plays a critical role in bridging the Visible Sphere with the Intelligible Sphere. (Kristeller 1990, Miles 1999, Yhap 2003) There are two modalities of the eye, the Mind's Eye or Inner Eye and the Physical or External Eye. The Mind's Eye feeds the soul directly with a higher level of reason and intelligence whereas the Physical Eye works on the Visible Sphere by simply reproducing and feeding images, shadows and reflections and not necessarily supplying the soul with a higher level of learning or understanding. (Clements 1954, Clements 1961, Clements 1965, Clements 1968, Saslow 1991, Vess 2009) The fact that Michelangelo depicted large eyeballs and optic nerve attests to the symbolic representations of the two modalities. (Figured 2F, 6B) The disembodied globes emphasize its role as an independent agent interacting with both the Intelligible and Visible Spheres, as a "tool of the divine". (Clements 1954)

There are ample references in his poetry and letters that allude to his lifetime preoccupation with the eyes and the perception of divine beauty. Heightened observational skills and keen knowledge of eye anatomy and physiology are evident in his writing:

The eyelid, with its shading, does not prevent my seeing when it contracts, but the eye is free from one end to the other in the socket in which it moves.

The eye, underneath the lid, moves slowly. The lid uncovers a small part of the large eyeball, revealing only a small part of its serene gaze.

The eye, being under the lid which covers it, moves up and down less. Thus, when not raised up, the lids have a shorter arc; they wrinkle less when extended more over the eye.

The whites of the eyes are white and the black more so than funeral drapes, if that is possible, and more than leonine the yellow which crosses from one fiber [vebre] to the next.

Michelangelo

(Clements 1965)

Throughout his lifetime, Michelangelo was obsessed with aesthetic beauty, intellect, and art. (Clements 1961) As evidenced in his letters and poems, his preoccupation with human vision through the exterior eye, and "perception/intelletto" or intellect through the brain, were ever present in his struggle to achieve "divine" perfection in his art. In 1991, Saslow interprets that for Michelangelo, "Divinely inspired idea(s) underlying the work, pre-exists the physical object and can survive it in the mind (or brain)". And it is through the eyes that divine ideas such as beauty rises to feed the soul and the intellect (brain). (Saslow 1991) 
The soul, the intellect complete and sound,

more free and unfettered, can rise through the eyes

up to your lofty beauty;

and,

Whatever beauty here on earth is seen,

To meet the longing and perceptive eye,

Is semblance of that source divine,

From whence we all are come.

In this alone we catch a glimpse of Heaven.

Michelangelo

(Saslow 1991) would raise himself towards the divine. In other words, the "ideating function of the artist" is to be the original creator, and to incorporate symbolic, learned ideas in amongst the background subjects in his paintings. (Miles 1999) The following excerpt by Michelangelo may also be a literal hint at his clever concealment of embedded images.

And it's no different with the roughest sketch:

before one's eager hand takes up the brush,

he checks and reworks the most beautiful and clever

of his learned ideas, and lays out his subjects.

Michelangelo

(Saslow 1991)

\section{Metaphorical Veil}

Metaphorical painting abounds in the Sistine Chapel. One of the most analyzed and graphic examples is in the Last Judgment panel that adorns the wall behind the altar. It depicts scenes from 'Dante's Inferno' from the epic poem, Divine Comedy by Italian poet Dante Alighieri, written between 1308 and his death in 1321. It is arguably the most important literary work in the Italian language and its allegorical view of heaven, hell, and purgatory remained an iconic religious influence for centuries beginning in the medieval ages. Barnes (1995) details the profound symbolic meanings of the painting and postulates that Michelangelo, like great poets, imitated the ancient philosophers by "hiding divine philosophy under the veil of poetry, so that they would not be understood by the common people". (Barnes 1995)

\section{Divine Intelletto}

In Neoplatonism, the capacity for the human mind and the higher soul to influence the handiwork stems from and is a reflection of 'The One' or God, and can only be appreciated by a higher level of intellect:

Good painting is nothing else but a copy of the perfections of God and a reminder of His painting. Finally, good painting is a music and a melody which intellect only can appreciate, and with great difficulty.

Michelangelo

(Gilbert 1980, Saslow 1991)

The concept of representing pure Ideas is at the highest realm of understanding, and as an artist, Michelangelo's capacity to depict these Ideas and be the creator of these ideal forms

\section{Neoplatonism by Raphael}

Two years after Michelangelo began work in the Sistine chapel, in 1510, Raphael (Raffaello Sanzio da Urbino [14831520]), a fellow painter and rival of Michelangelo, painted The School of Athens. It is considered a masterpiece of High Renaissance and emblematic of the teachings of classical Neoplatonism. Not only did it utilize mathematical proportions, geometry, architecture, and perspective developed by ancient Greek philosophers, it figuratively represented them as well, with Plato and Aristotle as central key figures. Plato is holding his book Timaeus and Aristotle, Nicomachean Ethics, both of which are giant literary works symbolizing the importance of Neoplatonic teachings.

It is good and useful, he (Michelangelo) tells Francisco de Hollanda (a visiting Portuguese miniature painter who meticulously transcribed Michelangelo's dialogue), to do one's work with dexterity and rapidity. It is a gift granted by God to be able to paint in a few hours what others spend several days painting.

Were it otherwise, Pausias of Sicyon (a famous Greek painter in the middle 4th century $B C$, celebrated for decorative paintings of boys and flowers) would not have worked so hard to paint in a single day the perfection of a child. Thus, if he who paints quickly does not for that reason paint worse than one who works slowly, he deserves as a consequence all the more praise. But if he, with the rapidity/ligereiza of his hand, should exceed certain limits, which one is not permitted to overstep in art, he ought rather to paint more slowly and studiously. For an excellent and skillful man does not have the right to let his tastes err through his indulgence in speed, if this indulgence causes him in any way to lose sight of or neglect his obligation of perfection. Hence, there is nothing wrong if one wants to paint a bit slowly, or very slowly if necessary, or even devote considerable time and effort, if this is done merely to achieve a greater perfection; lack of knowledge is the one defect. 
Michelangelo felt that with enough intellect and understanding of the subject matter, and the faster that an artist can depict the image, the closer to perfection one can be. (Clements 1961, Hirst 1988) It is intriguing that Michelangelo painted Separation of Light from Darkness, the first event in the Book of Genesis, as the final painting after four years of work in 1512. The fact that he completed this in one day shows the culmination of his acquired abilities in the rapidity of his masterful rendering skills. (Condivi 1903, King 2003) It is testament to his intellect and demonstrates his struggle to achieve the divine.

Clements (1965) translates Michelangelo's writing, "God is not only the master creator who empowers a select few artists to complete his task for him. He also supplies the lofty subject matter of art, the most noble being the human body itself." (Clements 1965, Hirst 1988)

\author{
He who made the whole made every part, \\ And then from the whole chose the most beautiful part, \\ To exhibit here below his most lofty creations, \\ As he has now done with his divine art.
}

\section{Conclusion}

No other master painter has left such an extensive literary body of work for generations to analyze than Michelangelo. Through his paintings, sketches, poems, letters, and documents, Michelangelo has left us an in-depth understanding of his spiritual beliefs, his profound subscription to Neoplatonism, and his regard of beauty, intellect, and art. In his dual worlds of Puritanical Christianity and Neoplatonism, Michelangelo cleverly rendered specific anatomic images as a symbolic way of ascension to higher spiritual realms toward the Divine or Ideal form. They represent an equally profound understanding of both Neoplatonic and archetypal religious worlds. Depicting Plato's "Allegory of the Cave" as a visual metaphor reflects his piety, his genius as an artist, and a devoted philosopher.

Disguised in a veil of symbolism, they represent his academic and spiritual quest to define the origins of the human soul and its concealment shows that it was not intended for the casual observer, but "people of perception" (people endowed with the gift of intellect or awareness of the divine realm). (Clements 1965) This, in the context of the progressive, scientific climate of the High Renaissance in Florence and influence from contemporaries like Raphael and Leonardo da Vinci, provides compelling evidence that helps explain why Michelangelo symbolically depicted neuroanatomical images in the Sistine Chapel.

\section{References}

Barnes B. 1995. Metaphorical Painting: Michaelangelo, Dante, and the Last Judgment. Art Bulletin. Vol. 77, No. 1:64-81.

Blunt A. 1940. Artistic Theory in Italy. London: Oxford University Press, 1940: 23-38, 58-81.

Boorstin DJ. 1993. The Creators: A History of Heroes of the Imagination. London: Vintage, 1993: 46-55, 407-419.

Burckhardt J. 1954. The Civilization of the Renaissance in Italy. New York: Random House, 1954: 312-351.

Casson H. Leonardo Da Vinci. 1977. Anatomical Drawings from the Royal Collection. London: Curwen Press; The Royal Academy of Arts.

Clarke E, Dewhurst K. 1996. An Illustrated History of Brain Function, 2nd Edition. San Francisco: Norman Publishing, 1996: 8-53, 54-58.

Clayton M, Philo R. 1992. Leonardo da Vinci: The Anatomy of Man. Drawings from the Collection of Her Majesty Queen Elizabeth II. Boston, Bulfinch Press.

Clements RJ. 1954. Eye, Mind, and Hand in Michelangelo's Poetry. PMLA, Vol. 69, No. 1, 324-336.

Clements RJ. 1961. Michelangelo's Theory of Art. New York, New York University Press; 1961:1-66.

Clements RJ. 1965. The Poetry of Michelangelo. New York: New York University Press.

Clements RJ. 1968. Michelangelo: A Self-Portrait. New York: New York University Press.

Condivi A, Holroyd C. 1903. The Life of Michael Angelo Buonarroti. Elibron Classics ed. London; New York: Duckworth and Co.; Charles Scribner's Sons.

Da Vinci L. 1977. Leonardo da Vinci: Anatomical Drawings from the Royal Collection. London: Royal Academy of Arts.

Del Maestro RF. 1998. Leonardo da Vinci: the search for the soul. J Neurosurg. 89:874-887.

Gilbert C. 1980. Complete Poems and Selected Letters of Michelangelo. Princeton: Princeton University Press, 5;33.

Hirst M. 1988. Michelangelo Draftsman. Washington, D.C.: Olivetti.

Holroyd C. 1903. Michael Angelo Buonarroti by Charles Holroyd; with translations of the life of the master by his scholar, Ascanio condivi, and three dialogues from the 
Portuguese by Francisco d'Ollanda. New York: C. Scribner's sons.

Keele KD, Pedretti C. 1979, 1980. Leonardo da Vinci. Corpus of Anatomic Studies in the Collection of Her Majesty the Queen at Windsor Castle, 3 vols. New York: Johnson Reprint Company.

King R. 2003. Michelangelo and the Pope's Ceiling. New York: Penguin Books.

Kristeller PO. 1943. The Philosophy of Marsilio Ficino. Gloucester: Columbia University Press.

Meshberger FL. 1990. An interpretation of Michelangelo's Creation of Adam based on neuroanatomy. JAMA. 264(14):1837-1841.

Miles MR. 1999. Plotinus on Body and Beauty: Society, Philosophy, and Religion in Third-century Rome. Oxford: Blackwell Publishers Inc.

Robb N. 1935. The Neoplatonism of the Italian Renaissance. London: George Allen \& Unwin. 57-89, 239-269.

Saslow JM. 1991. The Poetry of Michelangelo: An Annotated Translation. New Haven: Yale University Press, $77,166,324,400,402$.

Stephens JN. 1990. The Italian Renaissance: The Origins of Intellectual and Artistic Change Before the Reformation. New York: Longman, 137-150.

Suk I, Tamargo RJ. 2010. Concealed Neuroanatomy in Michelangelo's Separation of Light from Darkness in the Sistine Chapel. Neurosurgery. 66(5):851-861.

Summers D. 1972. Maniera and Movement: The Figura Serpentinata. Art Quarterly. 35:269-301.

Taylor AE. 1960. Plato: The Man and his Work. London: Methuen \& Co Ltd.

Vasari G, Bondanella JC, Bondanella PE. 1998. The Lives of the Artists. Oxford; New York: Oxford University Press, Inc.

Vess D. 2009. The Influence of Neoplatonism on Michelangelo. Georgia College \& State University [http://hercules.gcsu.edu/ dvess/micel.htm - accessed 6/15/2009]

Yhap J. 2003. Plotinus on the Soul: A Study in the Metaphysics of Knowledge. Selinsgrove: Susquehanna University Press.

\section{Acknowledgements}

The authors would like to thank Mr. Brandon J. Fiedor M.A. (who is the Managing Editor of Neurosurgery journal) for his hard work and careful review of the manuscript.

The authors are also indebted to Ms. April Ingram for her infinite patience and invaluable editorial assistance in finalizing the manuscript to its eventual publication.

\section{Authors' Biographical Sketches}

Mr. Ian Suk, B.Sc., B.M.C. is a Professor in the Johns Hopkins Department of Neurosurgery and has a joint appointment in the Department of Art as Applied to Medicine. He specializes in rendering complex imagery in neuroscience and teaches several courses to graduate students in Medical Illustration.isuk1@jhmi.edu

Rafael J. Tamargo, M.D. is a Professor of Neurosurgery in the Johns Hopkins Department of Neurosurgery who specializes in neurovascular and skull-base surgery to treat aneurysms, arteriovenous malformations (AVMs), cavernous malformations, and arteriovenous fistulas (AVFs) of the brain and spinal cord in both children and adults.

\section{Licensing}

The author has chosen to license this content under a Creative Commons Attribution, NonCommercial, NoDerivatives 4.0 International License.

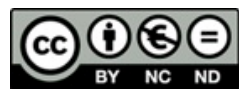

